\title{
Vaporization and thermodynamic properties of samarium dicarbide and sub-stoichiometric disamarium tricarbide
}

\author{
JOHN M. HASCHKE" \\ Rockwell International, Rocky Flats Plant, \\ P.O. Box 464, Golden, Colorado 80401. U.S.A. \\ and \\ THOMAS A. DELINE \\ Department of Chemistry, University of Michigan. \\ Ann Arbor, Michigan 48109, U.S.A.
}

(Received 3 August 1981; in revised form I April 1982)

\begin{abstract}
The vaporization reactions of $\mathrm{SmC}_{2}(\mathrm{~s})$ and $\mathrm{Pu}_{2} \mathrm{C}_{3}$-type $\mathrm{SmC}_{y}(\mathrm{~s}, 1.36<y<1.45)$ have been characterized and equilibrium pressures have been measured using a target-collection effusion technique. The carbides vaporize incongruently as follows:

$$
\begin{gathered}
\mathrm{SmC}_{2}(s)=2 \mathrm{C}(\mathrm{s})+\mathrm{Sm}(\mathrm{g}), \\
\{2 /(2-y)\} \mathrm{SmC}_{y}(s)=\{y /(2-y)\}, \mathrm{SmC}_{2}(s)+\operatorname{Sm}(\mathrm{g}) .
\end{gathered}
$$

The complex reaction for $\mathrm{SmC}_{y}$ occurs because the composition of the carbon-rich boundary of the phase decreases as temperature increases. For reaction (i), the equilibrium pressure is describcd by $\log _{10}\left\{\left(p / p^{\circ}\right)(\mathrm{Sm}, \mathrm{g}, 1548 \mathrm{~K}<T<2049 \mathrm{~K})\right\}=(3.60 \pm 0.01)-(14309 \pm 21)(T / \mathrm{K})$ The non-linear pressure equation for reaction (ii) is $\log _{10}\{(p / p)(\mathrm{Sm}, \mathrm{g}, 1.42<y<1.44,1372 \mathrm{~K}$ $<T<1636 \mathrm{~K})\}=\left\{12.009-28449(T / \mathrm{K})^{-1}+7018500(T / \mathrm{K})^{-2} \pm 0.038\right.$;. Thermodynamic values for the vaporization and formation reactions of $\mathrm{SmC}_{2}(\mathrm{~s})$ and $\mathrm{SmC}_{y}(\mathrm{~s})$ at $298.15 \mathrm{~K}$ have been calculated: $\Delta H_{\mathrm{f}}^{\circ}\left(\mathrm{SmC}_{2}, \mathrm{~s}, 298.15 \mathrm{~K}\right)=-(96.2 \pm 7.5) \mathrm{kJ} \cdot \mathrm{mol}^{-1}$ and $\Delta H_{\mathrm{f}}\left(\mathrm{SmC}_{1,43}, \mathrm{~s}, 298.15 \mathrm{~K}\right)=-(89.0 \pm 8.0) \mathrm{kJ} \cdot \mathrm{mol}^{-1}$. The thermodynamic results art discussed and compared with values reported for other lanthanide carbides.
\end{abstract}

\section{Introduction}

As noted in our recent report on the phase equilibria in (samarium + oxygen + carbon $){ }^{(1)}$ an interest in the thermodynamic properties of the lanthanide carbides at high temperatures is promoted by their importance in nuclear-reactor technology. The importance of the smarium system is enhanced by the behavior of that lanthanide as a neutron poison. The thermodynamic properties of $\mathrm{SmC}_{2}$ and of other lanthanide dicarbides have been extensively investigated and are reviewed in the compilation by Gschneidner and Kippenhan. ${ }^{(2)}$

a To whom correspondence should be addressed. 
Initial workers reported the existence of three carbide phases $\left(\mathrm{LnC}_{2}, \mathrm{Ln}_{2} \mathrm{C}_{3}, \mathrm{Ln}_{3} \mathrm{C}\right)$ for several lanthanides, ${ }^{(3)}$ and more recent studies have supported the existence of these phases in (samarium + carbon). ${ }^{(4)}$ The few results compiled for miscellaneous lanthanide carbides ${ }^{(2)}$ demonstrate that the investigation of their properties is limited. Values are presented for six $\mathrm{Ln}_{2} \mathrm{C}_{3}$ phases ( $\mathrm{Ln}=\mathrm{La}, \mathrm{Ce}, \mathrm{Pr}, \mathrm{Nd}, \mathrm{Sm}$, and Ho), but for none of the $\mathrm{Ln}_{3} \mathrm{C}$ phases. Furthermore, an unexpectedly wide variation is observed in the enthalpies of formation for $\mathrm{Ln}_{2} \mathrm{C}_{3}$ phases: $\Delta H_{\mathrm{f}}\left(\mathrm{Ce}_{2} \mathrm{C}_{3}, \mathrm{~s}\right.$, $298.15 \mathrm{~K})=-88.2 \mathrm{~kJ} \cdot \mathrm{mol}^{-1} ; \Delta H_{\mathrm{f}}\left(\mathrm{Sm}_{2} \mathrm{C}_{3}, \mathrm{~s}, 1531 \mathrm{~K}\right)=-254.4 \mathrm{~kJ} \cdot \mathrm{mol}^{-1}{ }^{1}$; and $\Delta H_{\mathrm{f}}^{\circ}\left(\mathrm{Ho}_{2} \mathrm{C}_{3}, \quad \mathrm{~s}, 298.15 \mathrm{~K}\right)=-58.2 \mathrm{~kJ} \cdot \mathrm{mol}^{-1}$. Since the average $\Delta H_{\mathrm{f}}\left(\mathrm{LnC}_{2}, \mathrm{~s}, 298.15 \mathrm{~K}\right)$ recommended for six lanthanides and yttrium is $-(97.9 \pm 10.5) \mathrm{kJ} \cdot \mathrm{mol}^{-1}$ (2) $^{(2)}$ the reliability of the values for the $\mathrm{Ln}_{2} \mathrm{C}_{3}$ phases must be questioned. Our investigation of the samarium carbides was motivated by a desire fully to characterize the vaporization behavior of a ( $\mathrm{Ln}+$ carbon) system, to address the apparent inconsistencies in thermodynamics of $\mathrm{Ln}_{2} \mathrm{C}_{3}$ and to provide initial thermochemical values for a representative $\mathrm{Ln}_{3} \mathrm{C}$ phase. (Samarium + carbon) was selected because of the apparent existence of four well-defined two-phase regions $\left(\mathrm{Sm}+\mathrm{Sm}_{3} \mathrm{C}, \mathrm{Sm}_{3} \mathrm{C}+\mathrm{Sm}_{2} \mathrm{C}_{3}, \mathrm{Sm}_{2} \mathrm{C}_{3}+\mathrm{SmC}_{2}, \mathrm{SmC}_{2}+\mathrm{C}\right)$ in which equilibrium vapor pressures could be measured.

The scope and direction of our effort has been substantially altered by the results of our reinvestigation of (samarium + oxygen + carbon). ${ }^{(1)}$ That study evolved from our inability to reproduce earlier results and yielded two major findings. (a) The existence of the cubic $\mathrm{Sm}_{3} \mathrm{C}$ phase could not be confirmed; however, an aniondeficient f.c.c. phase with identical lattice parameters was found at the $\mathrm{SmO}_{0.5} \mathrm{C}_{0.4}$ composition. (b) The cubic $\mathrm{Pu}_{2} \mathrm{C}_{3}$-type phase, designed as $\mathrm{SmC}_{y}$ in this report, was found to be sub-stoichiometric, to exist over the range $1.36<y<1.45$, and to have a carbon-rich phase boundary which decreased in carbon content with increasing temperature. The retrograde composition variation, which is attributed to anion altervalence involving acetylide $\left(\mathrm{C}_{2}^{2-}\right)$ and methanide $\left(\mathrm{C}^{4-}\right)$ ions and to shifts in the $\mathrm{C}_{2}^{2-}+6 \mathrm{e}^{-}=2 \mathrm{C}^{4-}$ equilibrium with temperature, has introduced unanticipated difficulties in the interpretation and evaluation of thermodynamic properties for $\mathrm{SmC}_{y}$. Although the scope of the investigation has been reduced by the absence of a $\mathrm{Sm}_{3} \mathrm{C}$ phase, a reinvestigation of $\mathrm{SmC}_{2}$ vaporization has been included to provide an internally consistent set of results for evaluating thermodynamic quantities across the system and to provide a mechanism for checking the accuracy of our pressure measurements with the results of other investigators. The phase equilibria and vaporization reactions of the carbides are described in the preceeding study which provides a basis for the present investigation. ${ }^{(1)}$

\section{Experimental}

\section{PREPARATION AND CHARACTERIZATION}

Samples of $\mathrm{SmC}_{2}$ and $\mathrm{SmC}_{y}$ were prepared by the reaction of samarium metal $(99.9$ moles per cent of rare earth, Rare Earth Research Corporation) with degassed powdered graphite (spectrographic grade. Ultracarbon) in sealed tantalum 
containers at a greatest temperature of $2200 \mathrm{~K} .{ }^{(1)}$ The preparative products and the condensed residues of vaporization experiments were analyzed by X-ray diffraction procedures; results were obtained with a Guinier-Haegg camera using $\mathrm{Cu} \mathrm{K} \alpha_{1}$ radiation and Si $(0.543062 \mathrm{~nm})$ as an internal standard. Metal and carbon contents were obtained by ignition in a carbon analysis train with gravimetric determination of residual $\mathrm{Sm}_{2} \mathrm{O}_{3}$ and Ascarite-collected $\mathrm{CO}_{2}$. All manipulations of the air-sensitive carbides were performed in a glovebox containing a recirculated $\mathrm{Ar}$ atmosphere which was purged of both water and oxygen.

The polycrystalline carbide samples used in the vaporization experiments were from reaction mixtures with $n(\mathrm{C}) / n(\mathrm{Sm})$ mole ratios of $2.0,1.6$, and 1.3 . $^{(1)}$ The product at the 2.0 mole ratio was a golden metallic $\mathrm{CaC}_{2}$-type phase with tetragonal lattice parameters of $a=(0.3771 \pm 0.0002) \mathrm{nm}$ and $c=(0.6316 \pm 0.0006) \mathrm{nm}$. The product at the 1.3 mole ratio was silver metallic and contained a $\mathrm{Pu}_{2} \mathrm{C}_{3}$-type phase with cubic parameters $a=(0.8399 \pm 0.0002) \mathrm{nm}$. This lattice parameter corresponds to that of the metal-rich boundary of the $\mathrm{Pu}_{2} \mathrm{C}_{3}$-type phase and implies that the sample was a mixture of $\mathrm{Sm}(\mathrm{s})$ and $\mathrm{SmC}_{1.35}(\mathrm{~s}) .{ }^{(1)} \mathrm{A}$ mixture of the cubic and tetragonal carbides was present at the 1.6 mole ratio. Effusion samples $(0.2$ to $0.4 \mathrm{~g})$ were finely crushed prior to use in vaporization experiments.

\section{VAPOR-PRESSURE MEASUREMENTS}

Equilibrium vapor pressures of samarium were measured using a target-collection effusion technique. As in previous studies with lanthanide carbides, ${ }^{(5,6)}$ molybdenum effusion cells with knife-edged orifices were used as containers. The orifice areas $\left(1.039 \times 10^{-3}, 2.523 \times 10^{-3}\right.$, and $\left.5.473 \times 10^{-3} \mathrm{~cm}^{2}\right)$ were determined from planimetric measurements of photomicrographs. For the $\left(\mathrm{SmC}_{2}+\mathrm{C}\right)$ and $\left(\mathrm{SmC}_{y}+\mathrm{SmC}_{2}\right)$ two-phase regions, pressure measurements were made both at successively increasing and decreasing temperatures in the 1548 to $2049 \mathrm{~K}$ and the 1372 to $1636 \mathrm{~K}$ ranges, respectively. Cell-cavity temperatures were measured using an optical pyrometer with a calibration traceable to N.B.S. The collection apparatus and $\mathrm{X}$-ray fluorescence procedures used for determining the quantity of samarium effusate condensed on the $\mathrm{Cu}$ target are described in a previous report. ${ }^{(7)}$

The experimental procedures were checked by measuring the apor pressure of gold (N.B.S. standard reference material 745) and verifying that the results were in agreement with the recommended values. Gold samples were contained in graphite effusion cells. The target collection and fluorescence procedures were identical to those used for the samarium carbides. For the vaporization of $\mathrm{Au}$, a third-law value of $\Delta H^{2}(298.15 \mathrm{~K})=(366.1 \pm 1.3) \mathrm{kJ} \cdot \mathrm{mol}^{-1}$ was obtained from 23 points. The recommended value is $(367.04 \pm 0.90) \mathrm{kJ} \cdot \mathrm{mol}^{-1}$.

\section{EQUILIBRIUM RESULTS}

\section{Results}

Both $\mathrm{SmC}_{2}(\mathrm{~s})$ and $\mathrm{SmC}_{y}(\mathrm{~s})$ vaporize incongruently with the formation of $\mathrm{Sm}(\mathrm{g})$ as the only significant vapor species. ${ }^{(1)}$ The dicarbide reaction shown by equation (1) has 
been thoroughly characterized in several mass-spectrometric studies reviewed by Seiver and Eick. ${ }^{(6)}$

$$
\mathrm{SmC}_{2}(\mathrm{~s})=2 \mathrm{C}(\mathrm{s})+\mathrm{Sm}(\mathrm{g}) .
$$

Equilibrium pressures for the process defined by equation (1) have been redetermined by 20 points obtained in three independent effusion experiments. The temperature dependence of the Sm pressure measured in the present study is described by

$$
\begin{aligned}
\log _{10}\{p(\mathrm{Sm}, \mathrm{g}, 1545 \mathrm{~K}<T<2049 \mathrm{~K}) / 101.325 \mathrm{kPa}] \\
=(3.60 \pm 0.01)-(14309 \pm 21)(T / \mathrm{K})^{-1}
\end{aligned}
$$

The second-law enthalpy and entropy of vaporization at the median temperature of $1799 \mathrm{~K}$ are $(273.9 \pm 0.4) \mathrm{kJ} \cdot \mathrm{mol}^{-1}$ and $(68.9 \pm 0.2) \mathrm{J} \cdot \mathrm{K}^{-1} \cdot \mathrm{mol}^{-1}$, respectively.

The vaporization reaction for $\mathrm{SmC}_{y}$ is described by

$$
\{2 /(2-y)\} \mathrm{SmC}_{y}(\mathrm{~s})=\{y /(2-y)\} \mathrm{SmC}_{2}(\mathrm{~s})+\mathrm{Sm}(\mathrm{g}) .
$$

The complex coefficients are a consequence of the retrograde dependence of the carbon-rich phase boundary of $\mathrm{SmC}_{y}$ on temperature. Previously described results of equilibrium studies for the temperature range of the vapor-pressure measurements show that the mole ratio $n(\mathrm{C}) / n(\mathrm{Sm})$ and the cubic lattice parameter of the $\mathrm{Pu}_{2} \mathrm{C}_{3}$ type phase both decrease with increasing temperature. ${ }^{(1)}$ At $1400 \mathrm{~K}, y=1.44$ and $a=0.8446 \mathrm{~nm}$; at $1600 \mathrm{~K}, y=1.42$ and $a=0.8434 \mathrm{~nm}$. The lattice parameter of $\mathrm{SmC}_{y}$ varies linearly with temperature over the range 1300 to $2200 \mathrm{~K}$, and it is reasonable to assume that Vegard's law is obeyed over the comparatively limited range of the vapor-pressure measurements; i.e. that $y$ decreases linearly with increasing temperature.

The equilibrium pressure of samarium for equation (3) has been measured at 22 temperatures in 7 independent effusion experiments. The values of $\log _{10}\{p / 101.325 \mathrm{kPa}\}$ are presented in table 1 and plotted against $T^{-1}$ in figure 1 . The five points indicated by solid circles are the average plateau pressures obtained during measurements along pressure-composition isotherms of (samarium + carbon) (compare figure 2 of reference 1). As shown in table 1, each of these points is based on three or more isothermal measurements in the composition range $1.45<n(\mathrm{C}) / n(\mathrm{Sm})<1.85$. Careful examination of figure 1 shows that the graph is not linear. The temperature dependence of $\log _{10}(p / 101.325 \mathrm{kPa})$ is described by a binomial relation:

$$
\begin{aligned}
\log _{10}\{p(\mathrm{Sm}, \mathrm{g}, 1372 \mathrm{~K} & <T<1636 \mathrm{~K}) / 101.325 \mathrm{kPa}\} \\
= & \left\{12.009-28849(T / \mathrm{K})^{-1}+7018500(T / \mathrm{K})^{-2}\right\} \pm 0.038 .
\end{aligned}
$$

An important aspect of the equilibrium process for $\mathrm{SmC}_{y}$ is reflected by the dependence of $\log _{10}(p / 101.325 \mathrm{kPa})$ on $(T / K)^{-1}$ being both non-linear and steeper than that for vaporization of $\mathrm{SmC}_{2}$. If a linear relation is used to approximate the values in figure 1 a slope of -18450 and an intercept of 8.53 arc obtained. As is cxpected from the fact that $\mathrm{SmC}_{2}$ is formed by vaporization of $\mathrm{SmC}_{y}$, the $\mathrm{Sm}$ activity at a given temperature in the $\left(\mathrm{SmC}_{y}+\mathrm{SmC}_{2}\right)$ region is higher than in the $(\mathrm{Sm}+\mathrm{C})$ region. However, use of the approximate slope to evaluate $\Delta H^{\circ}(1504 \mathrm{~K})$ for equation (3) 
TABLE 1. Equilibrium vapor pressure of $\operatorname{Sm}(\mathrm{g})$ for the vaporization reaction $\{2 /(2-y)\} \mathrm{SmC}_{v}(\mathrm{~s})=$ $\{y /(2-y)\} \mathrm{SmC}_{2}(\mathrm{~s})+\mathrm{Sm}(\mathrm{g}):^{a}$ orifice areas $a$

\begin{tabular}{|c|c|c|c|c|c|c|c|}
\hline No. & $\frac{10^{4} a}{\mathrm{~cm}^{2}}$ & $\frac{T}{\mathrm{~K}}$ & $-\log _{10}\left\{\frac{p(\mathrm{Sm})}{p}\right\}^{h}$ & No. & $\begin{array}{l}10^{4} \mathrm{a} \\
\mathrm{cm}^{2}\end{array}$ & $\begin{array}{l}T \\
\mathrm{~K}\end{array}$ & $-\log _{10}\left\{\frac{p(\mathrm{Sm})}{p}\right\}^{n}$ \\
\hline 1 & 2.523 & $\begin{array}{l}1458 \\
1458\end{array}$ & $\begin{array}{l}4.517 \\
4.537\end{array}$ & & & $\begin{array}{l}1473 \\
1386\end{array}$ & $\begin{array}{l}4.386 \\
4.217\end{array}$ \\
\hline 2 & 1.039 & $\begin{array}{l}1458 \\
1511 \\
1511\end{array}$ & $\begin{array}{l}4.524 \\
3.933 \\
3.991\end{array}$ & 6 & 1.039 & $\begin{array}{l}1575 \\
1575 \\
1575\end{array}$ & $\begin{array}{l}3.454 \\
3.485 \\
3.465\end{array}$ \\
\hline & & 1511 & 3.035 & 7 & 1.039 & 1495 & 4.117 \\
\hline 3 & 5.437 & $\begin{array}{l}1426 \\
1426 \\
1426\end{array}$ & $\begin{array}{l}4.762 \\
4.769 \\
4.851\end{array}$ & & & $\begin{array}{l}1531 \\
1551 \\
1608\end{array}$ & $\begin{array}{l}3.8 .33 \\
3.613 \\
3.213\end{array}$ \\
\hline 4 & 5.437 & $\begin{array}{l}1410 \\
1410 \\
1410 \\
1410\end{array}$ & $\begin{array}{l}4.936 \\
4.922 \\
4.909 \\
4.928\end{array}$ & & & $\begin{array}{l}1623 \\
1636 \\
1613 \\
1588 \\
1557\end{array}$ & $\begin{array}{l}3.107 \\
2.976 \\
3.212 \\
3.365 \\
3.610\end{array}$ \\
\hline 5 & 5.437 & $\begin{array}{l}1373 \\
1411 \\
1451\end{array}$ & $\begin{array}{l}5.207 \\
4.862 \\
4.555\end{array}$ & & & $\begin{array}{l}1513 \\
1509\end{array}$ & $\begin{array}{l}4.029 \\
4.098\end{array}$ \\
\hline
\end{tabular}

"The results are listed in chronological order of measurement. The average results of experiments 1 to 4 and 6 are shown by solid circles in figure 1 .

${ }^{\mathrm{h}} p=101.325 \mathrm{kPa}$.

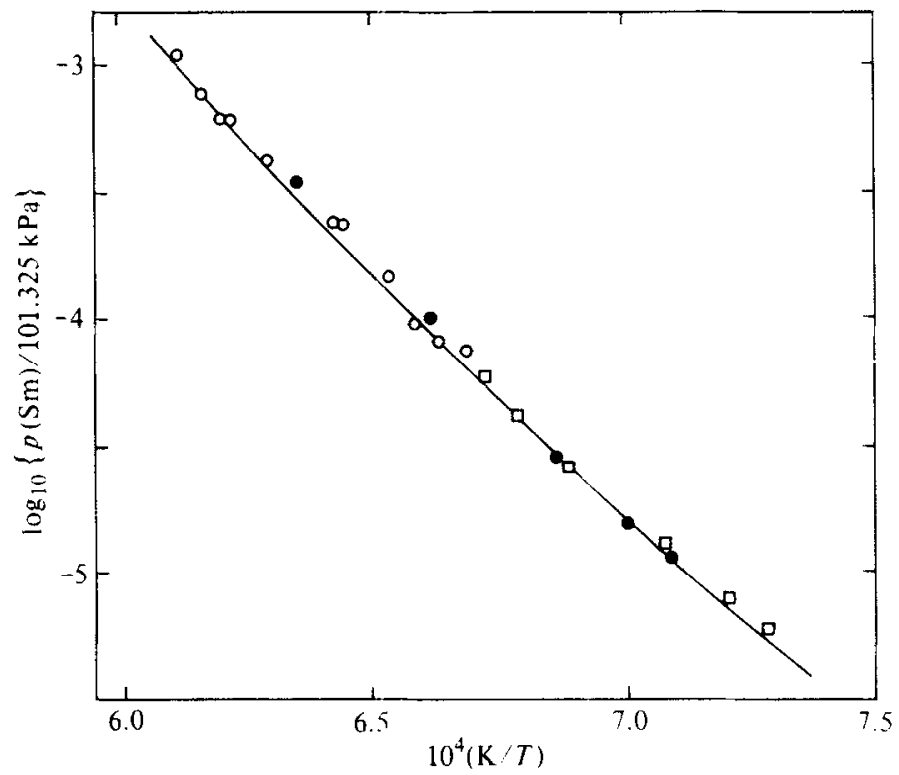

FIGURE 1. Dependence of $\log _{10}\left\{p(\mathrm{Sm}, \mathrm{g}) / 101.325 \mathrm{kPa} ;\right.$ on $(T / \mathrm{K})^{-1}$ for the $\left(\mathrm{SmC}_{\mathrm{v}}+\mathrm{SmC}_{2}\right)$ region in the range 1372 to $1636 \mathrm{~K}$. 
yields an apparent enthalpy of vaporization that is $79 \mathrm{~kJ} \cdot \mathrm{mol}^{-1}$ more positive than $\Delta H(1799 \mathrm{~K})$ for equation (1). These observations are inconsistent and demonstrate that thermodynamic quantities for equation (3) cannot be correctly evaluated using the second-law method. This conclusion is consistent with the temperature dependence of $y$ in equation (3). Since a different vaporization reaction occurs at each temperature, $\Delta H$ and $\Delta S$ for the process must be different at each temperature and can be obtained for a given $T$ and $y$ only by the third-law method.

\section{THERMODYNAMIC RESULTS}

The results of the equilibrium measurements have been reduced to $298.15 \mathrm{~K}$ using estimated thermal functions for $\mathrm{SmC}_{2}(\mathrm{~s})$ and $\mathrm{SmC}_{y}(\mathrm{~s})$. High-temperature heatcapacity equations for the carbides have been estimated from that of $\mathrm{Sm}_{2} \mathrm{O}_{3}(\mathrm{~s})$, $^{(8)}$ using the modified Kopp's-rule method. ${ }^{(9)}$ The resulting equations are of the form $C_{p} /\left(\mathbf{J} \cdot \mathbf{K}^{-1} \cdot \mathrm{mol}^{-1}\right)=A+B(T / \mathbf{K})+C(T / \mathbf{K})^{-2}$; the values for $A, B$, and $C$ are 77.0 , $9.71 \times 10^{-3}$, and $-9.00 \times 10^{-5}$ for $\mathrm{SmC}_{2}$ and $62.8,9 \cdot 7 \times 10^{-3}$, and $-9.00 \times 10^{-5}$ for $\mathrm{SmC}_{y}$. The calculated enthalpy and entropy increments are given in table 2 . As noted, the functions for $\mathrm{SmC}_{2}$ have been corrected for the tetragonal-to-cubic transition of the dicarbide at $1440 \mathrm{~K} \cdot{ }^{(10)} \mathrm{A}$ value of $\Delta H_{\mathrm{tr}}\left(\mathrm{SmC}_{2}, \mathrm{~s}, 1440 \mathrm{~K}\right)=5.57 \mathrm{~kJ} \cdot \mathrm{mol}{ }^{\mathrm{t}}$ has been obtained by adopting the enthalpy change reported for the tetragonal-to-cubic transition of $\mathrm{CaC}_{2}(\mathrm{~s})$. $^{(11)}$

Values of $S\left(\mathrm{SmC}_{2}, \mathrm{~s}, 298.15 \mathrm{~K}\right)=87.9 \mathrm{~J} \cdot \mathrm{K}^{-1} \cdot \mathrm{mol}^{-1}$ and $S\left(\mathrm{SmC}_{1.43}\right.$. $\mathrm{s}, 298.15 \mathrm{~K})=84.1 \mathrm{~J} \cdot \mathrm{K}^{-1} \cdot \mathrm{mol}^{-1}$ have been estimated using the adaptation of Latimer's method ${ }^{(12)}$ proposed for lanthanide solids by Westrum. ${ }^{(13)}$ In

TABLE 2. Estimated thermal functions for $\mathrm{SmC}_{2}(\mathrm{~s})$ and $\mathrm{SmC}_{1,4}(\mathrm{~s})$

\begin{tabular}{|c|c|c|c|}
\hline$\frac{T}{\mathrm{~K}}$ & $\frac{H(T)-H(298.15 \mathrm{~K})}{\mathrm{kJ} \cdot \mathrm{mol}^{-1}}$ & $\frac{S(T)-S(298.15 \mathrm{~K})}{\mathbf{J} \cdot \mathrm{K}^{1} \cdot \mathrm{mol}^{-1}}$ & $\frac{-(G(T)-H(298.15 \mathrm{~K})\} / T}{\mathrm{~J} \cdot \mathrm{K}^{-1} \cdot \mathrm{mol}^{-1}}$ \\
\hline \multicolumn{4}{|c|}{$\mathrm{SmC}_{2}$} \\
\hline 1400 & 91.34 & 124.8 & 147.5 \\
\hline \multicolumn{4}{|c|}{${ }^{\mathrm{a}}--------------------\cdots----$} \\
\hline $\begin{array}{l}1500 \\
1600 \\
1700 \\
1800 \\
1900 \\
2000\end{array}$ & $\begin{array}{l}105.99 \\
115.20 \\
124.24 \\
134.04 \\
143.16 \\
152.75\end{array}$ & $\begin{array}{l}1.34 .9 \\
140.8 \\
146.4 \\
151.8 \\
156.9 \\
161.8\end{array}$ & $\begin{array}{l}152.2 \\
156.7 \\
161.2 \\
165.2 \\
169.1 \\
173.3\end{array}$ \\
\hline \multicolumn{4}{|c|}{$\mathrm{SmC}_{1.43}$} \\
\hline 1400 & 75.93 & 103.1 & 133.0 \\
\hline \multicolumn{4}{|c|}{${ }^{\prime}-\ldots-----------\cdots-----------\cdots--$} \\
\hline $\begin{array}{l}1500 \\
1600\end{array}$ & $\begin{array}{l}83.47 \\
91.34\end{array}$ & $\begin{array}{l}108.3 \\
113.3\end{array}$ & $\begin{array}{l}136.8 \\
140.4\end{array}$ \\
\hline
\end{tabular}

" The $\Delta H_{\mathrm{tr}}$ of $5.57 \mathrm{~kJ} \cdot \mathrm{mol}^{-1}$ and $\Delta S_{\mathrm{tr}}$ of $3.87 \mathrm{~J} \cdot \mathrm{K}^{-1} \cdot \mathrm{mol}^{-1}$ for the tetragonal-to-cubic transition at $1440 \mathrm{~K}$ are included. 
adaptation of Latimer's method ${ }^{(12)}$ proposed for lanthanide solids by Westrum. ${ }^{131}$ In the $\mathrm{CaC}_{2}$-type lanthanide dicarbides, the cations are trivalent and the anions are acetylinic. ${ }^{(14)}$ In the stoichiometric $\mathrm{Pu}_{2} \mathrm{C}_{3}$-type phase, the same ionic species are present, ${ }^{(1)}$ and the metallic $\mathrm{SmC}_{2}$ and $\mathrm{SmC}_{1.43}$ phases are formulated as $\left(\mathrm{Sm}^{1 \mathrm{II}}\right)\left(\mathrm{C}_{2}^{2-}\right)\left(\mathrm{e}^{-}\right)$and as $\left(\mathrm{Sm}^{\mathrm{III}}\right)\left(\mathrm{C}_{2}^{2-}\right)_{0.68}\left(\mathrm{C}^{4-}\right)_{0.07}\left(\mathrm{e}^{-}\right)_{1.36}$, respectively. The entropies were obtained by combining Westrum's values for the lattice $\left(54.4 \mathrm{~J} \cdot \mathrm{K}^{-1} \cdot \mathrm{mol}^{-1}\right)$ and magnetic $\left(15.1 \mathrm{~J} \cdot \mathrm{K}^{-1} \cdot \mathrm{mol}^{-1}\right)$ contributions of $\mathrm{Sm}^{\text {[II }},{ }^{13}$ ) with the average lattice contribution $\left(13.8 \mathrm{~J} \cdot \mathrm{K}^{-1} \cdot \mathrm{mol}^{\cdots 1}\right)$ calculated for the $\mathrm{C}_{2}^{2 \cdots}$ ion. This value was derived from values of $S(298.15 \mathrm{~K})$ for nine acetylinic metal carbides $^{(11.15)}$ by subtracting their cationic contributions. The values of $-\left\{G^{c}(T)-H^{c}(298.15 \mathrm{~K})\right\} / T$ listed for the carbides in table 2 are based on these entropy estimates.

Thermodynamic values for vaporization of $\mathrm{SmC}_{2}$ according to equation (1) at $298.15 \mathrm{~K}$ have been calculated using thermal functions from table 2 and those of $\operatorname{Sm}(\mathrm{g}),{ }^{(16)}$ and $\left.\mathrm{C}(\mathrm{s})\right)^{(17)}$ Results obtained by the second- and third-law methods are presented in table 3. Values for $\Delta H_{\mathrm{f}}\left(\mathrm{SmC}_{2}, \mathrm{~s}, 298.15 \mathrm{~K}\right)$ in table 3 have been obtained from the vaporization results and $\Delta H_{\mathrm{f}}(\mathrm{Sm}, \mathrm{g}, 298.15 \mathrm{~K}){ }^{(16)}$ The value of $S\left(\mathrm{SmC}_{2}, \mathrm{~s}, 298.15 \mathrm{~K}\right)$, which was estimated for third-law calculations and obtained from the second-law $\Delta S^{\prime}(298.15 \mathrm{~K})$, and the values of $S(\mathrm{Sm}, \mathrm{g}, 298.15 \mathrm{~K}),{ }^{(16)}$ and $S(C, s, 298.15 \mathrm{~K}),{ }^{(17)}$ for second-law calculations have been used to derive values of $\Delta G_{\mathrm{f}}\left(\mathrm{SmC}_{2}, \mathrm{~s}, 298.15 \mathrm{~K}\right)$.

As discussed in the preceeding section, thermodynamic results for the vaporization of $\mathrm{SmC}_{y}(\mathrm{~s})$ have been evaluated only by the third-law method. The values of $y$ in equation (3) for three temperatures in the experimental range ${ }^{(1)}$ are presented with other pertinent data in table 4. Since - $\left.G^{\prime \prime}(T)-H(298.15 \mathrm{~K})\right\} / T$ values for $\mathrm{SmC}_{1.42}$ and $\mathrm{SmC}_{1.44}$ are virtually identical to those of $\mathrm{SmC}_{1.43}$. the values

TABLE 3. Thermodynamic values for vaporization and formation of $\mathrm{SmC}_{2}(\mathrm{~s})$ and $\left.\mathrm{SmC}_{1.4} \mid s\right)$ at $298.15 \mathrm{~K}^{\prime \prime}$

\begin{tabular}{|c|c|c|c|}
\hline & \multicolumn{2}{|c|}{$\mathrm{SmC}_{2}(\mathrm{~s})$} & \multirow{2}{*}{$\begin{array}{l}\mathrm{SmC}_{1+3}(s) \\
\text { Third law }\end{array}$} \\
\hline & Second law & Third law & \\
\hline$\Delta H(298.15 \mathrm{~K}) /\left(\mathbf{k J} \cdot \mathrm{mol}^{-1}\right)^{h}$ & $303.1 \pm 7.5$ & $311.0 \pm 1.7$ & 282.1 \\
\hline$\Delta S^{\prime}\left(298.15 \mathrm{~K} /\left(\mathrm{J} \cdot \mathrm{K}^{-1} \cdot \mathrm{mol}^{-1}\right)^{b}\right.$ & $101.7 \pm 6.3$ & $(106.3)^{-}$ & $(108.4)$ \\
\hline$\Delta H_{\mathrm{f}}(298.15 \mathrm{~K}) /\left(\mathrm{kJ} \cdot \mathrm{mol}^{-1}\right)$ & $-96.2 \pm 7.5$ & $-(104.3+3.3)$ & $-(89.9 \pm 8.0)$ \\
\hline$\Delta S_{\mathrm{f}}(298.15 \mathrm{~K}) /\left(\mathrm{J} \cdot \mathrm{K}^{-1} \cdot \mathrm{mol}^{-1}\right)$ & $11.7 \pm 6.3$ & $(7.1)$ & $16.7)$ \\
\hline$\Delta G_{\mathrm{f}}(298.15 \mathrm{~K}) /\left(\mathrm{kJ} \cdot \mathrm{mol}^{-1}\right)$ & $-99.5 \pm 8.0$ & $-(106.3)$ & -192.41 \\
\hline$S(298.15 \mathrm{~K}) /\left(\mathrm{J} \cdot \mathbf{K}-1 \cdot \mathrm{mol}^{-1}\right)$ & $92.5 \pm 6.3$ & $(87.9)$ & 184.11 \\
\hline
\end{tabular}

\footnotetext{
a Values in parentheses are based on the estimated values of $S\left(\mathrm{SmC}_{2} . \mathrm{s}, 298.15 \mathrm{~K}\right)=87.9$ $\mathrm{J} \cdot \mathrm{K}^{-1} \cdot \mathrm{mol}^{-1}$ and $S\left(\mathrm{SmC}_{1.43}, \mathrm{~s} .298 .15 \mathrm{~K}\right)=84.1 \mathrm{~J} \cdot \mathrm{K}^{-1} \cdot \mathrm{mol}^{-1}$. The uncertainties in second-law $\Delta H$ and $\Delta S$ and third-law $\Delta H$ for $\mathrm{SmC}_{2}(\mathrm{~s})$ include statistical variations from the analysis of results and a \pm 20 per cent uncertainty in estimated $\left\{H^{\prime}(T) \quad H(298.15 \mathrm{~K})\right\}$ and $\left\{S(T) \cdots S(298.15 \mathrm{~K})\right.$. For $\Delta H_{\mathrm{f}}(298.15 \mathrm{~K})$. $\Delta S_{\mathrm{f}}(298.15 \mathrm{~K})$, and $\Delta G_{\mathrm{f}}(298.15 \mathrm{~K})$ of $\mathrm{SmC}_{2}(\mathrm{~s})$, the uncertainties are accumulated values for the formation reaction. Statistical variations are not available for $\mathrm{SmC}_{1,4}(\mathrm{~s})$, and an estimated uncertainty of $3.0 \mathrm{~kJ} \cdot \mathrm{mol}^{-1}$ is included in its $\Delta H_{\mathrm{f}}(298.15 \mathrm{~K})$

b The vaporization reactions for $\mathrm{SmC}_{2}(\mathrm{~s})$ and $\mathrm{SmC}_{1.43}(\mathrm{~s})$ are given by equations (1) and (3), respectively.
} 
TABLE 4. Thermodynamic results for $\mathrm{SmC}_{y}(\mathrm{~s})$ in equilibrium with $\mathrm{SmC}_{2}(\mathrm{~s})$ and $\mathrm{Sm}(\mathrm{g})$ at compositions across the experimental temperature range

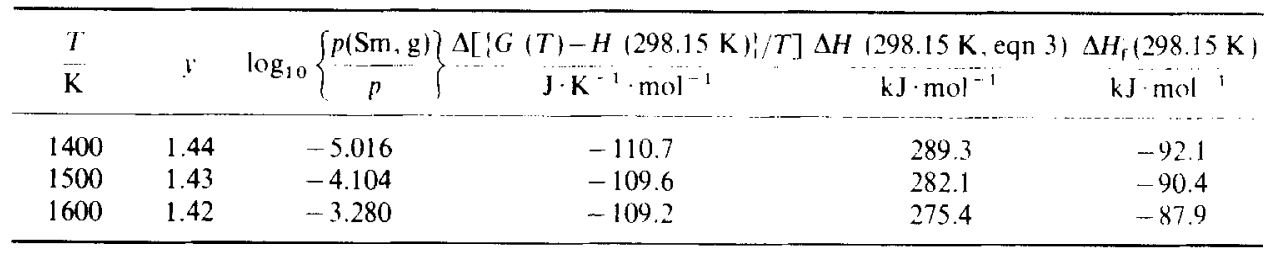

${ }^{a} p=101.325 \mathrm{kPa}$.

reported for the intermediate composition in table 2 have been used in all calculations. The resulting values of $\Delta H(298.15 \mathrm{~K})$ for equation (3) show a definite temperature trend which is reflected in the corresponding $\Delta H_{\mathrm{f}}\left(\mathrm{SmC}_{1.43}\right.$. s. $\left.298.15 \mathrm{~K}\right)$ derived using $\Delta H_{\mathrm{f}}(\mathrm{Sm}, \mathrm{g}, 298.15 \mathrm{~K})^{(16)}$ and the average $\Delta H_{\mathrm{f}}\left(\mathrm{SmC}_{2}, \mathrm{~s}, 298.15 \mathrm{~K}\right)$ from table 3. The other thermodynamic quantities for $\mathrm{SmC}_{1.43}$ in table 3 have been obtained using the results for $\mathrm{SmC}_{2}$, the estimated $\mathrm{S}^{\star}\left(\mathrm{SmC}_{1.43}, \mathrm{~s}, 298.15 \mathrm{~K}\right)$, and data for the elements. ${ }^{(16.17)}$

\section{Discussion}

The effusion results for $\mathrm{SmC}_{2}$ vaporization provide an alternate method for evaluating the accuracy of our pressure measurements. This capability is especially critical for establishing the fact that the concave upward curvature of $\log _{10}\{p(\mathrm{Sm}, \mathrm{g}) / 101.325 \mathrm{kPa}\}$ against $T^{-1}$ for the $\left(\mathrm{SmC}_{y}+\mathrm{SmC}_{2}\right)$ region does not result from an experimental effect such as secondary evaporation of samarium in the effusion apparatus. This is particularly important because the results of an earlier vaporization study in the range $1.7<n(\mathrm{C}) / n(\mathrm{Sm})<2.0$ by Avery et al. did not indicate anomalous behavior. ${ }^{(18)}$ Vapor-pressure equation $(2)$ is in good agreement with that measured by Seiver and Eick and with the result of several earlier studies reviewed in their report. ${ }^{(6)}$ The slope and intercept values for $\log _{10}\{p(\mathrm{Sm}, \mathrm{g}) / 101.325 \mathrm{kPa}\}$ against $(T / \mathrm{K})^{-1}$ obtained by Seiver and Eick are $-(14218 \pm 200)$ and $(3.84 \pm 0.11)$, respectively: the combined pressure equation obtained by Seiver and Eick from their results and the results of selected earlier reports has values of $-(13700 \pm 130)$ and $(3.54 \pm 0.09)$, respectively. Since secondary evaporation would be less in the lower-temperature range of the $\mathrm{SmC}_{y}$ measurements than in that of $\mathrm{SmC}_{2}$, the observed curvature in figure 1 can only be attributed to thermochemical properties of (samarium + carbon).

The pressure behavior in $\left(\mathrm{SmC}_{y}+\mathrm{SmC}_{2}\right)$ is unusual, but not unique. A similar upward curvature is observed in the plot of $\log _{10}\{p(\mathrm{Yb}, \mathrm{g}) / 101.325 \mathrm{kPa}\}$ against $(T / K)^{-1}$ for the sub-stoichiometric diytterbium tricarbide in equilibrium with ytterbium dicarbide. ${ }^{(19)}$ In that system, the phase-boundary composition of the substoichiometric phase is found to decrease in carbon content with decreasing temperature. An anomalous slope-relation of $\log _{10}\{p(\mathrm{Ho}, \mathrm{g}) / 101.325 \mathrm{kPa}\}$ against $(T / K)^{-1}$ is also found in (holmium + carbon). ${ }^{(20)}$ Although the second-law method was not used in evaluation, the obvious inconsistency was not discussed. These 
results suggest that a general feature of the $\left(\mathrm{LnC}_{1.5}+\mathrm{LnC}_{2}\right)$ equilibrium systems of the lanthanides, with the possible exception of $\mathrm{Eu}$, is an increasing sub-stoichiometry of the $\mathrm{LnC}_{1.5}$ phase with increasing temperature.

Our equilibrium pressures are not in good agreement with the results reported previously for $\left(\mathrm{SmC}_{1.5}+\mathrm{SmC}_{2}\right) .^{(18)}$ The earlier work shows a linear plot of $\log _{10}\{p(\mathrm{Sm}, \mathrm{g}) / 101.325 \mathrm{kPa}\}$ against $(T / \mathrm{K})^{-1}$ for the composition range $1.7<n(\mathrm{C}) / n(\mathrm{Sm})<2.0$. In addition, the absolute pressures differ substantially. Our pressures are consistently higher. The ratios $\{p(\mathrm{Sm}, \mathrm{g}$, this study $) / p(\mathrm{Sm}, \mathrm{g}$, Avery et al.) $\}$ at 1400,1500 , and $1600 \mathrm{~K}$ are $4.2,7.3$, and 13.7 , respectively.

A possible explanation for the difference in the effusion results is suggested by the time dependence of $p(\mathrm{Sm}, \mathrm{g})$ for $\left(\mathrm{SmC}_{y}+\mathrm{SmC}_{2}\right)$. The isotherms of $\log _{10}\{p(\mathrm{Sm}, \mathrm{g}) / 101.325 \mathrm{kPa}\}$ against time presented for $\mathrm{SmC}_{y}$ vaporization ${ }^{(1)}$ show that the pressure was initially constant for approximately $2 \mathrm{~h}$ at a value in agreement with pressure equation (4) and then began to decrease slowly. The results at 1440 and $1575 \mathrm{~K}$ are particularly instructive. The test at $1440 \mathrm{~K}$ was fortuitously terminated shortly after the pressure began to drop. Total mass-losses show that the terminal mole ratio $n(\mathrm{C}) / n(\mathrm{Sm})$ was $(1.87 \pm 0.03)$. The test at $1575 \mathrm{~K}$ continued for 2 to $3 \mathrm{~h}$ after the pressure began to drop below the plateau value of $33 \mathrm{~Pa}$. At termination, the measured pressure of $2.2 \mathrm{~Pa}$ was still a factor of 10 greater than the equilibrium value of $0.33 \mathrm{~Pa}$ calculated for $\mathrm{SmC}_{2}$ at $1557 \mathrm{~K}$ using equation (2). These results demonstrate that the measured effusion pressures in our tests decreased steadily when the $n(\mathrm{C}) / n(\mathrm{Sm})$ exceeded 1.85 or 1.90 .

Potential origins of such pressure-composition behavior include (a) the formation of a sub-stoichiometric dicarbide phase, $\mathrm{SmC}_{2-x}$, at high temperature, and (b) the formation of a product layer of $\mathrm{SmC}_{2}$ on the particles of $\mathrm{SmC}_{y}$. A graph of effusion pressures as the square root of time at $1575 \mathrm{~K}$ is linear, but the values are insufficient to establish unequivocally that the vaporization process is diffusion controlled. ${ }^{211}$ However, the formation of a product barrier is consistent with the results of our preliminary effusion experiments in which pressures werc measured at successively increasing and decreasing temperatures. Unless the sample was crushed very finely, the pressures observed on the descending sequence with a partially depleted $\mathrm{SmC}$, content were consistently lower than those in the ascending sequence with a fresh sample. If a product diffusion barrier forms, the composition at which the attainment of equilibrium is hindered will vary with temperature, effusion rate, and sample surface area. Since the pressures observed by Avery and co-workers are consistently lower than those of the present study and since they assumed only that the vapor in their cell was saturated, their measurements may well have been conducted at nonequilibrium conditions.

The validity of the results of the present study is evidenced by their excellent agreement with thermochemical values for neighboring lanthanide carbides. The values of $\Delta H_{\mathrm{f}}^{\circ}\left(\mathrm{CeC}_{2}, \mathrm{~s}, 298.15 \mathrm{~K}\right)$ and $\Delta H_{\mathrm{f}}\left(\mathrm{CeC}_{1.5}, \mathrm{~s}, 298.15 \mathrm{~K}\right)$ measured by oxygen bomb calorimetry are $-(97.0 \pm 5.4)$ and $-(88.2 \pm 2.9) \mathrm{kJ} \cdot \mathrm{mol}^{-1}$, respectively ${ }^{221}$ Our corresponding results for $\mathrm{SmC}_{2}$ and $\mathrm{SmC}_{1.5}$ are $-(96.3 \pm 7.5)$ and $-(89.9 \pm 8.0) \mathrm{kJ} \cdot \mathrm{mol}^{-1}$. Although the thermodynamic quantities for the dilanthanide tricarbides are quite limited, the solid-state e.m.f. measurements of 
Anderson and Bagshaw are the most extensive. ${ }^{(23)}$ In order to compare our results with their $\Delta G_{\mathrm{f}}\left(\mathrm{LnC}_{1.5}, \mathrm{~s}, 1100 \mathrm{~K}\right)$ results for several lanthanides. $\Delta I_{\mathrm{f}}^{\circ}\left(\mathrm{SmC}_{1.43}, \mathrm{~s}, 1100 \mathrm{~K}\right)$ and $\Delta S_{\mathrm{f}}\left(\mathrm{SmC}_{1.43}, \mathrm{~s}, 1100 \mathrm{~K}\right)$ have been calculated from the results in table 3 , thermal functions derived from the estimated $C_{p}\left(\mathrm{SmC}_{1.43}, \mathrm{~s}\right)$, and thermal functions for the elements. ${ }^{(17.18)}$ The results show $\Delta G_{\mathrm{f}}\left(\mathrm{SmC}_{1.43}, \mathrm{~s}, 1100 \mathrm{~K}\right)$ $=-(110.5 \pm 8.5) \mathrm{kJ} \cdot \mathrm{mol}^{-1}$. The average of the $\Delta G_{\mathrm{f}}^{\circ}\left(\mathrm{LnC}_{1,50}, \mathrm{~s}, 1100 \mathrm{~K}\right)$ values for $\mathrm{La}, \mathrm{Ce}, \mathrm{Pr}$, and $\mathrm{Nd}$ is $-(110.3 \pm 4.6) \mathrm{kJ} \cdot \mathrm{mol}^{-1}$. $^{(23)}$

The existence of sizeable discrepancies in the enthalpies of formation of the dilanthanide tricarbides is noted in the introduction. Examination of the original reports show that the differences are primarily a consequence of compilation error. ${ }^{(2)}$ The enthalpy of formation listed for $\mathrm{Ce}_{2} \mathrm{C}_{3}$ is actually the value for $\mathrm{CeC}_{1.50}$ and should be doubled. ${ }^{(23)}$ The compiled value for $\Delta H_{\mathrm{f}}\left(\mathrm{Sm}_{2} \mathrm{C}_{3}, \mathrm{~s}, 1531 \mathrm{~K}\right)$ is the enthalpy change for the vaporization of $\mathrm{Sm}_{2} \mathrm{C}_{3}(\mathrm{~s})$ to form $\mathrm{SmC}_{2}(\mathrm{~s})$ and $\mathrm{Sm}(\mathrm{g})$. $^{(18)}$

The equilibrium measurements and thermodynamic results of this study support the conclusions of our earlier report on (samarium + oxygen + carbon). The anomalous increase in the equilibrium pressure of gaseous samarium with temperature and the observed shift of $\Delta H_{\mathrm{f}}^{\circ}\left(\mathrm{SmC}_{y}, \mathrm{~s}\right)$ to less negative values with increasing temperature (compare table 4) are consistent with the fact that the carbonrich phase boundary of the $\mathrm{Pu}_{2} \mathrm{C}_{3}$-type samarium carbide has a significant retrograde temperature dependence.

Support of the U.S. Department of Energy, Contract DE-AC04-76DP03533, during preparation of the manuscript is gratefully acknowledged.

\section{REFERENCES}

1. Haschke, J. M.: Deline, T. A. Inorg. Chem. 1980, 19, 527.

2. Gschneidner, K. A.; Kippenhan, N. Rep. IS- RIC 5, Institute for Atomic Research, Iowa State University, Ames, Iowa. 1971.

3. Spedding, F. H.; Gschneidner, K. Jr, Daane, A. H. J. Am. Chem. Soc, 1958, 80, 4499.

4. Boerner. G.: Goergenyi. T.: Pierre. V. Prakt. Metallogr. 1972, 9. 431

5. Haschke, J. M.; Eick, H. A. J. Phys. Chem. 1968, 72, 1697.

6. Seiver, R. L.; Eick, H. A. High Temp. Sci. 1971, 3, 292.

7. Haschke, J. M. High Temp. Sci. 1977, 9, 77.

8. Pankratz, L. B.; King, E. G.; Kelley, K. K. U.S. Bur. Mines Rept. 6033. 1962.

9. Haschke, J. M.; Eick. H. A. Inorg. Chem. 1970, 9, 851

10. Krikorian, H. H.; Wallace, T. C.; Bowman, M. G. Colloq. Int. C.N.R.S. 1967, 157. 489.

11. Wicks, C. R.; Block, F. E. U.S. Bur. Mines Bull. 605.1963.

12. Latimer, W. M. J. Am. Chem. Soc. 1951, 73, 1480.

13. Westrum. E. F. Adv. Chem. Ser. 71, 1967, 25.

14. Atoji, M. J. Chem. Phys. 1961, 35, 1950.

15. Schumm, R. H.; Wagman, D. D.; Bailey, S. ; Evans, W. H. : Parker, V. B. Natl Bur. Stand. Tech. Note $270-7.1973$.

16. Hultgren, R.; Desai, P. D.; Hawkins, D. T.; Gleiser, M.; Kelley, K. K.; Wagman, D. D. Selected Values of the Thermodynumic Properties of the Elements. Am. Soc. Metals: Metals Park. 1973.

17. Stull, D. R.: Prophet. H. JANAF Thermochemical Tables 2nd edition. NSRDS-NBS 37. 1971.

18. Avery, D. F.; Cuthbert. J.; Silk, C. Br. J. Appl. Phi's. 1967, 18, 1133; Harwell Rept. AERE-R 5148 1966.

19. Haschke, J. M.; Eick. H. A. High Temp. Sci. 1970, $2,376$.

20. Wakefield, G. F.; Daane. A. H.; Spedding, F. H. Prof. Conf. Rare Earth Res. 4th. 1965, p. 469.

21. Hulbert, S. F. J. Br. Ceram. Soc. 1969, 6, 11.

22. Baker, F. B.; Huber, E. J., Jr.; Holley, C. E., Jr.; Krikorian. N. H. J. Chem. Thermodynamics 1971, 3, 77 .

23. Anderson, J. S.; Bagshaw. A. N. Rev. Chim. Miner. 1972, 9, 115. 